\title{
Public water and waste management in Uganda: the legal framework, obstacles and challenges
}

\author{
By Asiimwe JACKLINE
}

\begin{abstract}
Access to public services in developing countries is always inefficient and resistant to reform. Despite substantial investments in public water and waste management in Uganda, coverage and service levels have failed to improve as expected due to sluggish progress. Whereas there may be substantial legal framework in place, there are challenges and obstacles which affect adequate access to these services. Only $32 \%$ of Ugandans have access to safe water supply, while only $19 \%$ have access to basic sanitation. This is partly attributed to lack of enforcement and weak punitive measures in the relevant legal framework. Other challenges include, poor management, corruption, politicization and lack of the requisite political will, rapid population growth, poor infrastructure, lack of technical capacity, and poor financing. The government has devised among others private takeover of some public services by profit maximising companies which in turn alienates the poor from accessing them. Therefore this desk review suggests the way forward towards a sustainable public water and waste management.
\end{abstract}

\section{Introduction and General Background}

Over the last two decades, progress on access to safely water services has been snail-paced globally. Global access slightly improved from $61 \%$ in 2000 to $71 \%$ in 2017 and that of sub-Saharan Africa from $18 \%$ in 2000 to $27 \%$ in $2017 .{ }^{1}$ Only $32 \%$ of Ugandans have access to basic water supply, while $19 \%$ have access to basic sanitation and seven million Ugandans practice open defecation. On the other hand, Uganda is facing rapid urbanization of $51 \%$ per annum, leading to overcrowding, development of slums, informal settlements and generation of large quantities of waste yet there is a poor public water and waste management practice. $^{2}$

Noteworthy, water remains the most essential commodity to human and other forms of life. As such, attention should be paid not only to regulating the exploitation of water and diminishing pollution but also protecting the entire ecosystems of which water resources constitute an integral part of a country's economy and should be protected and enhanced

1 WHO/UNICEF, Progress on Household Drinking Water, Sanitation and Hygiene 2000-2017. New York, 2019, WHO/UNICEF Joint Monitoring Programme.

2 MoWE, Joint Sector Review Report, 2010. 
accordingly. ${ }^{3}$ Public water quality and quantity are important considerations for its intended use. Whereas water may be plentiful most of it unsuitable for human use because of contamination. This problem is more serious, particularly in urban areas where the need to provide adequate and safe supplies of water and dispose of increasingly large quantities of waste in safe and environmentally sound way is an increasingly pressing concern. ${ }^{4}$

More importantly, when public water and waste are not properly managed, waste finds its way in water sources which in turn affects the quality of human life and more specifically impacts on the full enjoyment of human rights. The duty to maintain and manage thriving public water and waste systems should lie squarely in the hands of the government and its citizens as opposed to divesture. Given the fact that Uganda is highly endowed with fresh palatable water, the government should be able to ensure low cost subsidised access to water resource by all citizens. The citizens together with the government, city and local councils should jointly ensure proper management of public water infrastructure and proper waste disposal.

This study covers residential piped water, most of which is provided by the National Water and Sewerage Corporation in large cities, boreholes, protected springs, wells and dams provided by the government to its citizens. The Directorate of Water Development (DWD) is charged with providing overall technical oversight for the planning, implementation and supervision of the delivery of urban water and sanitation services across the country whereas the National water and Sewerage Corporation (NWSC) manages the large urban centres across the country.

To provide conducive operational atmosphere for the DWD and NWSC, it should be noted that Uganda has put in place a comprehensive regulatory framework although there are underlying weaknesses in the punitive provisions and lack of enforcement. Therefore, the subsequent section of this work will briefly analyse the existing legal framework and assessing its workability in maintaining sustainable public water and waste management in Uganda. This will be preceded by discussion of challenges and obstacles as well as suggesting suitable recommendations, conclusions and possible way forward.

\section{The Legal Framework on Public Water\& Waste Management in Uganda}

As already noted, Uganda has a comprehensive legal regime relating to public water and waste management. Nevertheless, the barriers relating to proper public water and waste management in Uganda arise from the existing the regulatory gaps, weak punitive provisions and lack of enforcement that arises out of lack of political will by high ranking government officials. This section will highlight relevant provisions in the law applicable and cite relevant examples to justify the foregoing statement.

3 UNEP, Training Manual on International Environmental Law, 2006, UNEP Nairobi, Kenya, p.253.

4 Supra note 2. 
The Constitution of the Republic of Uganda, 1995 enjoins the State to provide clean and safe water to the citizenry. ${ }^{5}$ It is also the role of the State to take all practical measures to promote a good water management system at all levels of government in Uganda. ${ }^{6}$ Relatedly, the government has to ensure that her citizens enjoy the right to a clean and healthy environment. ${ }^{7}$ Further, Article 245 of the Constitution requires Parliament to take specific actions concerning the environmental protection - 'Parliament shall, by law, provide for measures intended to protect and preserve the environment from abuse, pollution and degradation; to manage the environment for sustainable development; and to promote environmental awareness.' It is also the duty of every citizen of Uganda to protect a clean and healthy environment. Further provisions on such duties are embodied in Uganda's framework on environmental law especially the National Environment Act (NEA) which was promulgated following the codification of Article 39 of the Constitution of Uganda.

National Environmental Act 5, 2019 Part VIII thereof provides for management of waste. A person who generates or handles waste shall be responsible for its proper management in accordance with this Act. The person responsible shall take reasonable steps necessary to prevent environmental pollution arising from such waste management. The Act also prohibits littering. ${ }^{8}$ The Act therefore penalizes both commissions and omission that are deemed to pollute the environment. Thus a person who contravenes any provision of the Act commits an offence and is liable on conviction to a fine not exceeding five hundred and fifty currency points. Under section 99, the Act prohibits the importation and exportation of waste save for those who acquire a license. A person who withholds information about the mismanagement of hazardous waste, or pollution commits an offence and is liable on conviction to a fine not exceeding fifty thousand currency points or imprisonment not exceeding fifteen years or both. ${ }^{9}$

The Water Act Cap. 152 defines waste to include sewage, any other matter or thing, whether wholly or partly in solid, gaseous state which if added to water may cause pollution. The long title states that 'an Act to provide for the use, protection and management of water resources and supply; to provide for the constitution of water and sewerage authorities; and to facilitate the devolution of water supply and sewerage undertakings. Section 5 provides that all rights to investigate, control, protect and manage water in Uganda for any use is vested in the Government and shall be exercised by the line minister and director in accordance with the Act. Section 31 prohibits any person from allowing waste to come into contact with any water, or discharging waste directly or indirectly into water and polluting water. Section 39 provides for offences relating to wastage, misuse, excessive consumption

5 Objective XIV of the National Objectives and Directive Principles of State Policy.

6 Objective XXI of the National Objectives and Directive Principles of State Policy.

7 Article 39.

8 Section 96 \& 97. Littering refers to disposing waste in a place not designated as a disposal area or waste collection point. One currency point is equivalent to twenty thousand shillings.

9 Section 162. 
or taking or using water for purposes provided by permit commits an offence. Section 40 provides for penalties being a term of imprisonment of not more than five years or to a fine of six million shillings and is liable to a fine of one million shillings for every day during which the offence is continued.

Better still, the Local Governments Act Cap. 243 (as Amended) provides for the decentralization of powers, services and resources from central government to local government with the aim of increasing local democratic control, participation in decision making, and mobilizing local support for development activities relevant to local needs. In this way the Local Government Act provides an opportunity for the district to enact laws as well as formulating policy regarding ecological sanitation.

This Act further defines the roles for different levels of government in provision and management of water and sanitation related activities. It also stipulates that the provision of water and maintenance of facilities is a role of Local Governments in liaison with the Ministry responsible for Water Affairs. The provisions of this law are vital in as far as taking services of provision and maintenance of water and sanitation to the people is concerned. However, limited funding is allocated from the local government and in most cases due to the challenge of entrenched corruption this money is always swindled. This largely explains why most water points are broken down and abandoned and no proper waste management in place. $^{10}$

The Land Act Cap 227 vests all rights to water resources in the Government. It empowers the Minister responsible for water to regulate the management and utilization of such water. The Act allows for reasonable use by the occupier or owner of a piece of land, of water for domestic and small-scale agricultural purposes. The Act provides that the government or local government holds land in trust for the people and protects environmentally sensitive areas such as natural lakes, rivers, groundwater, natural ponds, natural streams, wetlands, forest reserves, national parks and any other land reserved for ecological and tourist purposes for a common good of the citizens of Uganda. The local government is designed to complement the mandate and efforts of central government as a medium through which these rights can be fulfilled. As such, local governments have high stake and mandate in different sectors including water and environment. ${ }^{11}$

Notably, the National Water and Sewerage Corporation (NWSC) Act, 2000 establishes the NWSC as a Water and Sewerage Authority and gives it the mandate to operate and provide water and sewerage services in areas entrusted to it on a sound commercial and viable basis. The Statute requires the Minister responsible for Water Affairs to enter into a performance contract with NWSC in relation to its operations in accordance with the provisions of the Water Act. The Act empowers the NWSC to own assets in its areas where it provides

10 Resty Naiga et al, Challenging pathways to safe water access in rural Uganda: From supply to demand- driven water governance, International Journal of the Commons, March 2015, Vol. 9, No. 1 (March 2015), pp. 237-26.

11 IDRC \&CRDI, Realizing Social Rights under the Decentralization System in Uganda, 2018, p.2. 
services without the need of compensation in respect of the transfer of such assets. In performance of its functions the entity and its employees have immunity. ${ }^{12}$ Under the new legal framework, the powers and structure of the NWSC were revised to enable the corporation to operate on a commercial and financially viable basis. This has resulted into high tariffs which in turn lead to affordability issues for the poor and illegal water connections and improper disposal waste.

Additionally, the Public Health Act, Cap. 281, part IX thereof provides for proper sanitation and housing. It prohibits nuisance to the effect that no person shall cause a nuisance, or shall suffer to exist on any land or premises owned or occupied by him or her or of which he or she is in charge, any nuisance or other condition liable to be injurious or dangerous to health. It enjoys the local authorities to maintain cleanliness and prevent nuisances. Every local authority shall take all lawful, necessary and reasonably practicable measures for maintaining its area at all times in clean and sanitary condition, and for preventing the occurrence in the area of, or for remedying or causing to be remedied, any nuisance or condition liable to be injurious or dangerous to health and to take proceedings at law against any person causing or responsible for the continuance of any such nuisance or condition.

\section{Challenges and Obstacles to Public Water and Waste Management}

The above highlighted legislation provides guidance for public water and waste management in Uganda. As it can be seen, these laws reflect underlying weaknesses and gaps, which pave way for numerous challenges and obstacles to proper public water and waste management as follows:

Lack of enforcement mechanism: The existing laws on public water and waste management are not effectively enforced. This is largely attributed to inherent weaknesses in the laws themselves. Therefore, the sector operates with little or no regulation. ${ }^{13}$ Similarly, the enforcement agencies for instance NEMA lack the requisite capacity to enforce the said provisions. NEMA has no personnel whose to oversee the enforcement of the provisions of the law and hence these provisions remain idle on paper, which defeats the purpose for which they were enacted. It has been said that these enforcement agencies are sleeping giants or toothless barking dogs.

As such, whereas the legal framework of seems good on paper, in practice these laws are not effectively implemented. The action plans aimed at implementing them are often unrealistic and impractical. Thus, implementation often fails because of lack of involve-

12 Section 34.

13 Liyala C.M., 2011, Modernizing Solid Waste Management at Municipal Level: Institutional Arrangements in East Africa, PhD Thesis, Environmental Policy Series, Wageningen University, Netherlands. 
ment and commitment of stakeholders at all levels. ${ }^{14}$ Through decentralization, power and decision making is vested in the lowest local government level. Responsibility for the delivery of water and waste services now lies with the district and town council levels. All cost for access, installation and maintenance of social basic and infrastructural services at to be met by local funding and initiatives. In the face of inadequate finances, the end result is illegal connections, abandonment of broken down water and waste point.

Coupled with this is the weak punitive measures stated under these laws, some of the pieces of legislation are archaic and do not cover the novel developments. The weak punitive measures could be partly explained by the fact that the custodians of these laws own large enterprises which they have to protect through enactment of laws with weak fines which they can easily afford when they contravene the law. The other related challenge is that it is very expensive for existing businesses to convert or change line of production to that which is environmentally friendly. ${ }^{15}$ In Uganda, a chain of polythene and plastic manufacturing and importing companies have been said to have a link to the political elites. This explains why several bans on the manufacture of polythene have been flouted. Improperly disposed polythene and plastic waste could take over a thousand years without decomposition. ${ }^{16}$ They clog drainage channels and lead to flooding in low lying areas which has sometimes led to loss of lives and property.

Public water and waste management like other sectors is poorly financed because it is not prioritised. ${ }^{17}$ Funding is normally from external sources mainly donors in form of grants. This means this means that these sectors cannot functions properly due to lack of fiscal autonomy. ${ }^{18}$ Yet the provision of these services requires huge sums of money. The absence of this money clearly illustrates how public water and waste management faces financial dilemma. It is difficult to solve this dilemma because urban and local councils obtain limited revenue from local sources. Whereas the Local Government Act provides for charging fees for waters and waste management services, the larger percentage of the community are not willing pay. Therefore households not served by resort to fetching water from unprotected sources and mishandling of waste. These include burning, burying in the back yard or indiscriminate open dumping. Waste composting is on a small insignificant scale for individual household use while anaerobic biogas production is limited and can be found only on high income generating farms in urban and rural areas. ${ }^{19}$

14 Seppala, O. 2002. Effective water and sanitation policy reform implementation: need for systematic approach and stakeholder participation. In Water Policy 4 (2002) issue 4.

15 For example the polythene bags and plastic products pose a huge danger to the environment because when carelessly disposed they end up in the drainage channels and the environment at large.

16 Interview with an official at Coca cola plastic recycling plant.

17 Liyala(supra note 13).

18 Okot-Okumu \& Nyenje, 2011, Municipal Solid Waste Management under Decentralized Uganda, Habitat International 35, pp.537and 543.

19 The biggest challenge for composting is indiscriminate unsorted waste collection which causes a health hazard to those who sort it and absence of market for compost. 
Although the NWSC is highly hailed as a successful public water and sewerage entity in sub Saharan Africa, it is challenged by absence of political will and politicization. ${ }^{20}$ There is lack of political will to enforce the provisions of these laws to the letter but are rather implemented on a political discriminatory basis.

Politicization of the sector, public water and waste was used as a 'vote catcher' whoever supplies it in the quantities required, is certainly regarded by politicians as very important. High politicization of water supply as opposed to equitable pro-poor approach NWSC projects were used as an avenue through which the NRM could build its popularity to the urban electorate. Rather than aiming to cause overall improvements in service delivery, the ruling class made electoral pledges targeting specific groups, such as the inhabitants of informal settlements.

In the run-up to the 2006 presidential elections, President Museveni pledged that, if elected, every village in the informal settlements of Kampala would get least one public standpipe. This pledge obliged NWSC to install 1,255 standpipes in 2006 alone, far more than the total of 600 standpipes that the 2003-2006 corporate plan had targeted for three years. The standpipes responding to the presidential campaign pledge were painted yellow, to symbolise ruling party colours. The NWSC also applied a $10 \%$ discount on an already subsidised standpipe tariff. The customers felt that water was a political gift from the president and therefore free of charge. Thus, while NWSC registered a $58 \%$ increment in new connections (from 14,045 in 2004 to 22,218 in 2005), the majority were low-income customers, who either paid less or completely defaulted on their water bills. ${ }^{21}$

Politicization was documented by an investigative journalist Mujuni (2013), the vacancy was opened up to the public, and a consultancy firm, KPMG, shortlisted six strong candidates for the position of executive director of NWSC. Two candidates who were senior staff in NWSC made it to the final stage but only one was to be selected between two senior Engneer Alex Gisagara and Engineer Silver Mugisha. In a space of two years, there was failure to agree on a single candidate. In the name of protecting the organisation, President Museveni intervened in this matter on the invitation of the minister for water. He sided with the water minister that Eng. Mugisha should be appointed the next CEO, even though the board had preferred Eng. Gisagara.

To meet the expectations, a cosmetic expansion was embarked on using pipes that are so small that they will not cope with the demand in the next five years. The cost of relying on such low-quality water networks result in the long run with increased water losses, reduced service reliability and poor water quality. The deterioration in quality and reliability of service causes disquiet among NWSC customers, whose willingness to pay diminishes, while others resort to illegal water connections.

20 Badru Bukenya, Pockets of Effectiveness Working Paper No. 10, The politics of building effective water utilities in the global South: A case of NWSC Uganda, 2020, ISBN: 978-1-912593-64-4.

21 Ibid. 
Owing to divesture and foreign aid, the NWSC is highly hailed as the most remarkable transformation of highly inefficient to profit making autonomous body. However, the said privatisation is not people driven but aims at collection of illicit revenue by the government. Public water and waste services are very essential for every country and should be provided at a no or very low subsidised cost by the government to the citizens. Whereas the government of Uganda argues that divesture of the public water was necessary in order to reduce the burden of the government and inclusion of private sector, it not people driven. This is because divesture is profit driven leading to high cost for access to public water and waste services which alienates by the majority poor.

Absence of adequate technical personnel to provide highly skilled services is yet another obstacle to a thriving public water and waste management system in Uganda. Like all developing countries, Uganda is no exception; there exists a gap in the provision of highly skilled professional services in the area of water and waste. This leaves these entities with an option to hire semi-skilled personnel or expatriates. This too negatively impacts proper public water and waste management in Uganda. In addition, there has been a deliberate failure by the government to include environmental education both in the school curriculum and outside the formal education system. This has led to public water and waste management to stand out as one of the greatest challenges which require urgent attention.

Corruption and poor leadership which is not pro people, resources allocated for public water and waste greedy individuals for self-gain. This implies that poor small weak pipes and connection materials are procured to cover up for the monies corruptly swindled. Yet as years progress, the pressure on these water supply pipes mounts up leading to low or no access to water in piped areas. This explains why the World Bank attributed the poor performance of NWSC to corruption, managerial challenges and weaknesses in government supervision. Due to these ills, the revenue collecting authority had threatened to shut NWSC head office, while the electricity company had plans to cut off the treatment plants for non-payment and it took foreign aid to revive it.

Closely linked to corruption is the challenge of poor infrastructure in place; small pipes with 'spaghetti capacity' are installed. Spaghetti networks are poor quality water networks characterised by several small pipes that keep multiplying on the same section as demand grows. Similarly, it is a common sight in urban centers to witness open burst pipes water pipes on one hand and sewage flowing on the surface of roads on the other. This could go on for days while residents cry for help in vein.to no avail. The installation of low quality small pipes over time lead to lack sustainable clean water and waste management and loss of water due to pipe bursting. On the other hand, public water management requires expensive equipment for purification, temporary storage and distribution especially in the country side. Several infrastructure in place with are with limited capacity and abandoned when they break down. This compels people to resort to cheap unprotected water sources.

Levying high waste collection fees has' led to littering, and unscrupulous dumping. This can be attributed to lack of capacity to pay waste collect fees. Collection fees ranges from at least US\$1 and above which is too high for poor. Waste collection fees are put in 
place by private companies which decides how much to charge depending on the bulkiness and nature of waste collected which leads to non-uniformity. Given the high waste collections fees levied, many people resort to using unconventional methods of disposal which include burning, burying in the backyards, reckless indiscriminate dumping in water drainage channels, streams, road sides, home surroundings. This subsequently blocks drainage channels causing flooding in low lying areas during rainy season, unpleasant odours and contamination of water sources.

Lack of sensitization, the public is not aware of the dangers of poor waste management and lack of access to clean and safe water. Most urban slums fetch from contaminated shallow wells, semi-protected water springs where water is free of charge. Although on the face of it this water may appear clean, it is unfit for domestic use due to contamination. This largely exposes a high population of Ugandans to water borne diseases and increases expenditure, loss of lives and aggravates poverty levels.

There is a challenge of absence of a culture of sorting waste, by type at generation points in this case households, commercial centers and institutions. This results into mixing biodegradable wastes with plastics and other environmental contaminating materials which are later disposed in the landfills. The public has not taken positive steps in waste management practices like source reduction, re-using, recycling or properly disposing of the portion that cannot be reclaimed. The public maintains and I don't care attitude of improper disposal of waste. This requires urgent attention to address.

There is also increased pressure on these services due to rapid population growth, increased urbanization and industrialization, uncontrolled environmental degradation and pollution. This pressure still remains a big challenge to the sustainable management and development of country's water and waste resources. Population increase leads to high pressure exerted on these services. Unable to match this pressure, these services deteriorate and break down. This exposes the community to widespread of diseases.

In light of the above discussion and conclusions and propose way forward for effective public water and waste management.

\section{Conclusions}

Public water supply and waste management are one of the key intervention areas for poverty eradication. Poor sanitation coupled with unsafe water sources increases the risk of water borne diseases due to poor hygiene contributing largely to high disease burden in Uganda. Whereas Uganda has a comprehensive public water and waste management legal framework in place, there is a challenge of lack of enforcement and weak punitive measures. Other challenges and obstacles include; poor management, politicization and lack of the requisite political, corruption, poor infrastructure in place, rapid population growth, lack of technical capacity, and poor financing. 


\section{Way Forward}

In light of the foregoing discussion and conclusions, to achieve and maintain a sustainable and thriving public water and waste management services, I recommend that;

The government should put in place strong functional law enforcement mechanisms as well as enhance the weak punitive measures to ensure deterrence.

There should be increased budgetary allocations to ensure good performance, efficiency and effectiveness backed by political will.

There is need to expand current service coverage to the whole country including both low income urban settlements and rural areas.

Private sector participation should only be encouraged for non-profit making entities in order to maintain affordability of these services. The government should maintain control over these basic services to ensure that all citizens have either free or subsidized access.

Undertaking regular community cleaning where a day can be set aside to clean up illegally established dumping sites is equally vital.

There is need to sensitize the community through coordinated capacity building on public water and waste management. The community can also be sensitized about the need to avoid generating unnecessary waste. For instance shops use plastic bottles and polythene bags as package materials which end up in drainage channels. Waste reuse, recycling into valuable items for usage keep waste materials in circulation rather than disposal which in turn harms the environment. Metal scrap can be converted into steel, plastic waste into plastic containers, artisan finished products, vegetable and food husks used for animal feeds as waste reduction and management option.

Finally, waste collection, storage and final disposal should be carried out by town council which levies and collects taxes from urban centers. The city councils may also delegate this responsibility to appointed private entities.

\section{References}

Bukenya, B., Pockets of Effectiveness Working Paper No. 10, The politics of building effective water utilities in the global South: A case of NWSC Uganda, 2020, ISBN: 978-1-912593-64-4.

Failler.P., et al, An Assessment of Environmental Pollution and its Impact on Economic Cooperation and Integration of IGAD Region, National Environment Pollution Report, DOI:10.13140/ RG.2.1.2830.2480.

Fraceys.R. et al, Improved Access to Urban Water Services in Uganda, 2009, DOI:10.1680/ muen.2009.162.3.165

IDRC \&CRDI, Realizing Social Rights under the Decentralization System in Uganda, 2018.

Liyala C.M., 2011, Modernizing Solid Waste Management at Municipal Level: Institutional Arrangements in East Africa, PhD Thesis, Environmental Policy Series, Wageningen University, Netherlands.

MoWE, Joint Sector Review Report, 2010. 
Okot-Okumu \& Nyenje, 2011, Municipal Solid Waste Management under Decentralized Uganda, Habitat International 35, pp.537and 543.

Resty Naiga et al, Challenging pathways to safe water access in rural Uganda: From supply to demanddriven water governance, International Journal of the Commons, March 2015, Vol. 9, No. 1 (March 2015).

Seppala, O. 2002. Effective water and sanitation policy reform implementation: need for systematic approach and stakeholder participation. In Water Policy 4 (2002) issue 4.

UNEP, Training Manual on International Environmental Law, 2006, UNEP Nairobi, Kenya.

WHO/UNICEF, Progress on Household Drinking Water, Sanitation and Hygiene 2000-2017. New York, 2019, WHO/UNICEF Joint Monitoring Programme.

Wilson D.C. et al, 2020, Comparative Analysis of Solid Waste Management in Cities around the World, Paper delivered at UK Solid Waste Association, Nov. 2010.

Ziraba et al A Review and Framework for Understanding the Potential Impact of Poor Solid Waste Management on Health in Developing Countries. Arch Public Health 74, 55 (2016). https://doi.org/10 $.1186 / \mathrm{s} 13690-016-0166-4$ 